Original Research Paper

\title{
Pelatihan Pembuatan Masker peel-off Lidah Buaya (Aloe vera) Untuk Mengatasi Efek Sunbur
}

\author{
Windah Anugrah Subaidah ${ }^{1}$, Wahida Hajrin ${ }^{1}$, Yohanes Juliantoni ${ }^{1}$ \\ ${ }^{\text {I} P r o g r a m ~ S t u d i ~ F a r m a s i, ~ F a k u l t a s ~ K e d o k t e r a n, ~ U n i v e r s i t a s ~ M a t a r a m, ~ M a t a r a m, ~ I n d o n e s i a ~}$
}

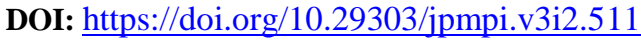

Sitasi: Subaidah, W.A., Hajrin, W., \& Juliantoni, H. (2020). Pelatihan Pembuatan Lidah Buaya (Aloe vera) Untuk Mengatasi Efek Sunburn. Jurnal Pengabdian Magister Pendidikan IPA, 3(2)

\section{Article history}

Received: 7 September 2020

Revised: 28 Oktober 2020

Accepted: 14 November 2020

*Corresponding Author:

Subaidah

Program Studi Farmasi,

Fakultas Kedokteran,

Universitas Mataram, Mataram,

Indonesia

Email:

windahanugrah@gmail.com

\begin{abstract}
Abstrak: Tingginya angka pengangguran di kota Mataram diantaranya kurangnya pendidikan dan keterampilan dari tenaga kerja. Lulusan SMA membutuhkan keterampilan untuk menciptakan lapangan pekerjaan dan mengurangi angka pengangguran. Salah satu peluang wirausaha adalah dengan membuat masker peel off lidah buaya (Aloe vera). Hal ini dilatar belakangi oleh intensitas matahari yang tinggi didaerah Indonesia yang cenderung menimbulkan efek negatif pada kulit terutama sunburn. Bahan baku lidah buaya yang mudah diperoleh dan mempunyai aktivitas sebagai antiinflamasi dari sunburn. Metode pelaksanaan pengabdian untuk memecahkan masalah mitra siswa SMAIT Anak Sholeh Mataram terdiri dari tiga tahapan yaitu persiapan kegiatan, pelaksanaan kegiatan, dan monitoring dan evaluasi. Hasil kegiatan pengabdiaan menunjukkan bahwa peserta memberikan tanggapan yakni peserta merasa pelatihan ini bermanfaat, proses pembuatan sediaan mudah dan pesesrta akan membuat masker lidah buaya. Tanggapan lainnya yakni penyajian materi menarik, materi yang disajikan mudah dipahami dan secara umum peserta puas terhadap kegiatan pengabdian masyarakat pembuatan masker lidah buaya ini
\end{abstract}

Kata Kunci: Pelatihan, Aloe vera, masker peel off, sunburn

\section{Pendahuluan}

Kota Mataram merupakan salah kota di Provinsi Nusa Tenggara Barat dengan jumlah penduduk usia kerja pada Agustus 2019 diperkirakan sejumlah 361.679 orang. Jumlah penduduk penganggur atau sedang aktif mencari pekerjaan masih cukup tinggi yakni sejumlah 19.928 orang (Badan Pusat Statistik Kota Mataram, 2019). Penyebab tingginya angka pengangguran di kota Mataram diantaranya kurangnya pendidikan dan keterampilan dari tenaga kerja. Salah satu lembaga pendidikan formal yang diakui oleh Undang-undang adalah Sekolah Menengah
Atas (Menteri Pendidikan dan Kebudayaan Republik Indonesia, 2019).

SMAIT Anak Sholeh Mataram merupakan salah satu sekolah swasta yang berlokasi di Jalan Pondok Indah, Lingkungan Pekandelan, Kelurahan Jempong Batu, Kecamatan Sekarbela Kabupaten Kota Mataram. SMAIT Anak Sholeh Mataram berada dibawah Yayasan Pendidikan Islam Terpadu Ibnu Abbas. Visi SMAIT anak Sholeh Mataram adalah terwujudnya Lembaga Pendidikan terbaik dalam membentuk generasi yang sholeh, madiri cerdas dan Tangguh berdasarkan Al-Quran dan Sunnah. Bertolak dari visi SMAIT Anak Sholeh Mataram tersebut maka sudah menjadi tanggung jawab 
bagi penyelenggara Pendidikan dilingkungan tersebut untuk menyiapkan peserta didik yang mempunyai sumber daya manusia mandiri yang siap bersaing dalam mendapatkan pekerjaan maupun dalam dunia usaha. Masalah yang dihadapi siswa SMAIT anak Sholeh Mataram adalah kurangnya bekal berketarampilan berwirausaha yang kurang. Padahal berwirausaha adalah salah satu pilihan untuk menciptakan lapangan pekerjaan dan mengurangi angka pegangguran. Selain itu kewirausahaan sangatlah penting untuk menciptakan generasi muda khususnya remaja yang memiliki daya saing tinggi.

Indonesia merupakan negara tropis yang memiliki intensitas matahari yang tinggi (Septiadi, Nanlohy, Souissa, \& Rumlawang, 2009). Sinar matahari atau sinar ultraviolet dengan intensitas tinggi dapat menyebabkan efek negatif bagi kesehatan terutama kulit. Efek negatif yang ditimbulkan sinar ultraviolet yakni sunburn, pigmentasi, penuaan dini hingga kanker kulit (Wilson, Moon, \& Armstrong, 2012).

Sunburn merupakan keadaan kulit yang terbakar disebabkan terlalu lama terpapar sinar UV. Radiasi sinar UVA dan UVB berperan penting dalam sunburn, terutama UV B yang secara langsung merusak DNA dengan menginduksi formasi dimmers timin-timin siklobutan (Wilson, Moon, \& Armstrong, 2012). Sunburn menginduksi terjadinya inflamasi yang menyebabkan vasodilatasi pembuluh darah. Karakteristik klinik yang ditemukan pada inflamasi yakni eritema, panas, bengkak dan nyeri (Suh et al., 2007). Untuk mengurangi efek inflamasi dari sunburn maka dapat mengaplikasikan gel lidah buaya (Jama Patient, 2015).

Lidah buaya merupakan tanaman asli daerah tropis Madagaskar, Saudi Arabia dan Iran. Tanaman lidah buaya termasuk kedalam family Liliaceae dengan daun yang berwarna hijau, tebal dan panjang. Pada tepi daun terdapat gerigi kecil (Bhuvana, Hema, \& Patil, 2014). Studi invitro menunjukkan lidah buaya dapat mengurangi inflamasi, memiliki sifat regeneratif dan meningkatkan produksi kolagen. Kandungan lidah buaya yang memiliki efek anti inflamasi dan mengurangi eritema yakni glukomanan, polisakarida seperti manosa, zink, kalsium, asam amino dan enzim (Hekmatpou, 2019).

Tingginya aktivitas siswa diluar rumah menjadi peluang bagi daun lidah buaya untuk dimanfaatkan sebagai produk pencegah sunburn dan mengurangi efek inflamasi. Sayangnya pemanfaatan daun lidah buaya masih belum optimal. Lidah buaya hanya dijadikan sebagai tanaman hias dipekarangan rumah. Berdasarkan survei yang dilakukan siswa masih banyak belum mengetahui manfaat lidah buaya terhadap kesehatan, adapun beberapa siswa yang paham akan manfaat lidah buaya hanya memanfaatkan lidah buaya secara tradisional.

Dibutuhkan teknologi sediaan farmasi untuk mengemas lidah buaya menjadi suatu produk yang praktis, efektif dan mudah diterima dimasyarakat. Berdasarkan alasan tersebut maka lidah buaya diformulasikan kedalam sediaan masker wajah. Sediaan masker merupakan sediaan farmasi dapat berupa krim atau gel yang penggunaannya di wajah dan dibiarkan selama 15-30 menit hingga mengering. Masker wajah lebih diminati karena penggunaannya yang praktis, efek hidrasi lebih tinggi dan stabilitas lebih baik (Rigano, 2014).

Berdasarkan masalah yang dihadapi mitra, yakni perlunya peningkatan pengetahuan dan keterampilan pemanfaatan lidah buaya sebagai masker wajah maka perlu diadakan pelatihan pembuatan pembuatan masker lidah buaya (Aloe vera) sebagai salah satu bekal keterampilan berwirausaha siswa SMAIT Anak Sholeh Mataram.

\section{Metode}

Metode pelaksanaan untuk memecahkan masalah mitra siswa SMAIT Anak Sholeh Mataram terdiri dari tiga tahapan yaitu 
persiapan kegiatan, pelaksanaan kegiatan, dan monitoring dan evaluasi.

Persiapan kegiatan meliputi penyiapan dan pembuatan bahan/ materi pelatihan dan pelatihan. Selain menyiapkan bahan presentasi tim pengabdian juga menyiapkan leaflet untuk memberikan informasi tambahan. Pada tahapan ini juga tim pengabdian melakukan preformulasi sediaan masker lidah buaya (Aloe vera) di Laboratorium Farmasetika, Program Studi Farmasi, Fakultas Kedokteran, Universitas Mataram. Proses preformulasi dilakukan untuk mengetahui apakah formulasi yang akan dibuat sudah memenuhi standar sediaan masker gel yang baik.

Pada tahap pelaksanaan kegiatan dilaksanakan dengan pertama-tama melakukan presentasi terkait lidah buaya dan manfaatnya bagi Kesehatan kemudian dilanjutkan dengan diskusi, tanya jawab dan pelatihan pembuatan sediaan masker gel lidah buaya (Aloe vera)

Evaluasi dilakukan untuk melihat ketercapaian dari target luaran program pengabdian. Evaluasi dilakukan dengan membagikan angket yang berisi beberapa pertanyaan terkait kegiatan pembuatan sediaan masker gel lidah buaya (Aloe vera).

\section{Hasil dan Pembahasan}

Seringnya kulit manusia terpapar sinar matahari akibat aktivitas yang tinggi diluar ruangan menyebabkan kerusakan kulit. Kerusakan kulit yang paling cepat dirasakan adalah perubahan warna kulit yang kemerahan dan kulit terasa terbakar (Geraldine, 2017). Solusi dari permasalahan tersebut adalah dengan menggunakan masker lidah buaya (Aloe vera). Lidah buaya (Aloe vera) terbukti dapat mengurangi inflamasi dan dapat diformulasikan kedalam sediaan farmasi. Penelitian Subaidah (2020) memformulasikan lidah buaya (Aloe vera) kedalam formulasi krim. Penelitian lainnya menunjukkan lidah buaya dapat diformulasikan kedalam sediaan gel dan dapat mengurangi efek efek inflamasi sunburn sinar matahari (Jama Patient, 2015).
Pengabdian masyarakat dengan tema "Pelatihan pembuatan masker lidah buaya (Aloe vera) untuk mengatasi efek sunburn" dilaksanakan pada tanggal 21 Oktober 2020 di SMAIT Anak Sholeh Mataram yang berlokasi di Jalan Pondok Indah, Lingkungan Pekandelan, Kelurahan Jempong Batu, Kecamatan Sekarbela Kabupaten Kota Mataram. Kegiatan berlangsung selama 2 jam yaitu dari pukul 09.30 WITA hingga pukul 11.30 WITA. Peserta pelatihan adalah siswa SMAIT Anak Sholeh Mataram.

Alur kegiatan pengabdian masyarakat diawali dengan sambutan. Sambutan pertama yakni dari ketua pengabdian, kemudian dilanjutkan oleh sambutan kepala SMAIT Anak Sholeh Mataram sekaligus membuka acara pengabdian gambar 1 .

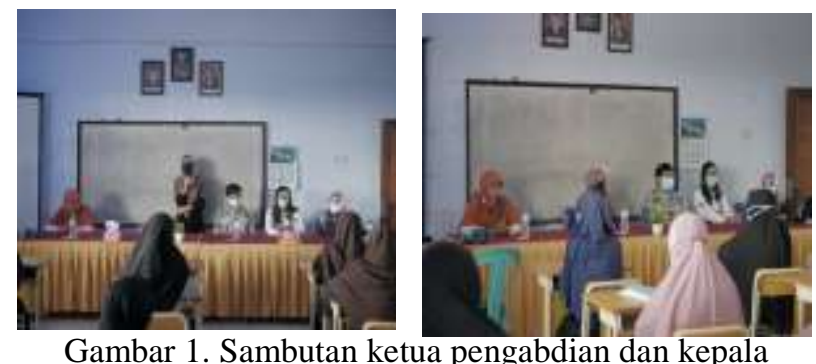

Gambar 1. Sambutan ketua pengabdian dan kepala SMAIT Anak Sholeh Mataram

Dilanjutkan paparan materi terkait manfaat lidah buaya untuk mengatasi sunburn. Materi yang diberikan antara lain pengertian sunburn, cici-ciri sunburn pada kulit, efek negatif paparan sunburn yang berulang, morfologi tumbuhan lidah buaya, penelitian tentang lidah buaya. Bahasan kedua terkait sediaan farmasi yang dapat dibuat dari lidah buaya.

Kegiatan selanjutnya adalah pengolahan lidah buaya menjadi sari lidah buaya. Penyaji memberikann demonstrasi tentang ekstraksi sari lidah buaya. Pertama-tama lidah buaya dipisahkan bagian daging buahnya dengan bagian daun luar yang berwarna hijau. Kemudian sebanyak $250 \mathrm{~g}$ daging lidah buaya dihaluskan menggunakan hand blender. Lidah 
buaya yang telah hancur kemudian disaring menggunakan saringan.

Tahap selanjutnya yakni pembuatan basis masker. Bahan-bahan yang digunakan dalam pembuatan lidah buaya dapat dilihat pada tabel 1.

Tabel 1. Formula masker lidah buaya (Aloe vera)

\begin{tabular}{ll}
\hline Nama bahan & Konsentrasi $(\%)$ \\
\hline Sari lidah buaya & 10 \\
Polivinil alkohol & 10 \\
Carbopol 940 & 1 \\
Propilen glikol & 10 \\
Metil Paraben & 0,2 \\
TEA & 0,5 \\
Etanol 95\% & 6 \\
Aquadest & Ad 100 \\
\hline
\end{tabular}

Polivinil alkohol (PVA) digunakan dalam sediaan masker sebagai pembentuk lapisan film sehingga mudah ketika masker akan dilepas (Sunnah, Mulasih \& Erwiyani, 2018). Carbopol 940 sebagai gelling agent yang dapat memberikan konsistensi gel pada sediaan masker (Sari, Nurbaeti \& Pratiwi, 2016). Propilen glikol dalam sediaan masker berperan sebagai humektan yakni menahan kandungan air dalam sediaan agar tidak terevaporasi dari sediaan (Hendradi et all., 2013). Metil paraben digunakan sebagai pengawet. TEA berfungsi sebagai adjufant $\mathrm{pH}$. Etanol 95\% digunakan sebagai pembantu kelarutan (Rowe, Sheskey \& Quinn, 2009).

Proses pembuatan basis masker dimulai dengan mengembangkan Carbopol 940 diatas air hangat. Kemudian dibuat larutan dengan cara melarutkan PVA ke dalam air panas. Carbopol 940 yang telah dikembangkan dicampur dengan larutan PVA (Campuran 1). Sebelumnya ditempat terpisah metil paraben dilarutkan kedalam propilen glikol kemudian menambahkan etanol 95\% (Campuran 2). Selanjutnya campuran 2 di tuang kedalam campuran 1 diaduk hingga homogen ditambahkan sisa air. Kemudian TEA ditambahkan sambil terus diaduk hingga homogen dan membentuk bassis gel. Terakhir sari lidah buaya ditambahkan kedalam basis sediaan gel. Sediaan masker gel kemudian dipindahkan ke dalam wadah yang telah disiapkan (gambar 2)

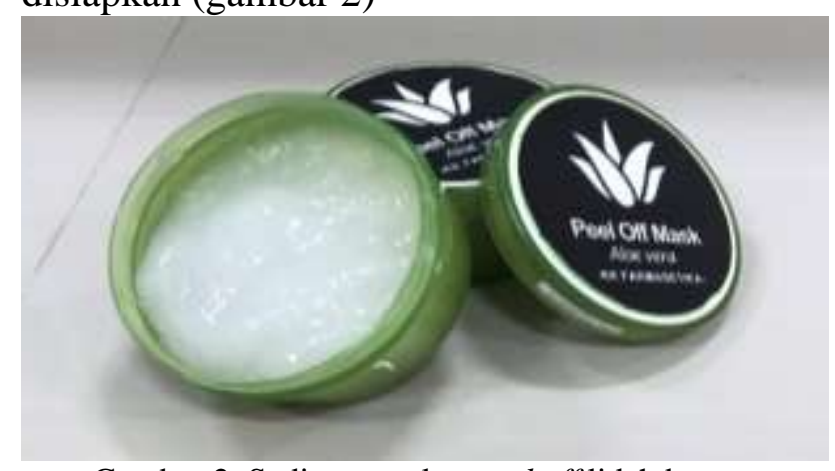

Gambar 2. Sediaan masker peel off lidah buaya

Peserta sangat antusia dalam proses pembuatan masker karena dapat mempraktekkan langsung pembuatan masker lidah buaya. Selain itu, juga mengajukan pertanyaan terkait proses pembautan masker lidah buaya. Pertanyaannya antara lain suhu air yang digunakan untuk melarutkan PVA dan berapa lama yang digunakan untuk mengembangkan Carbopol 940.

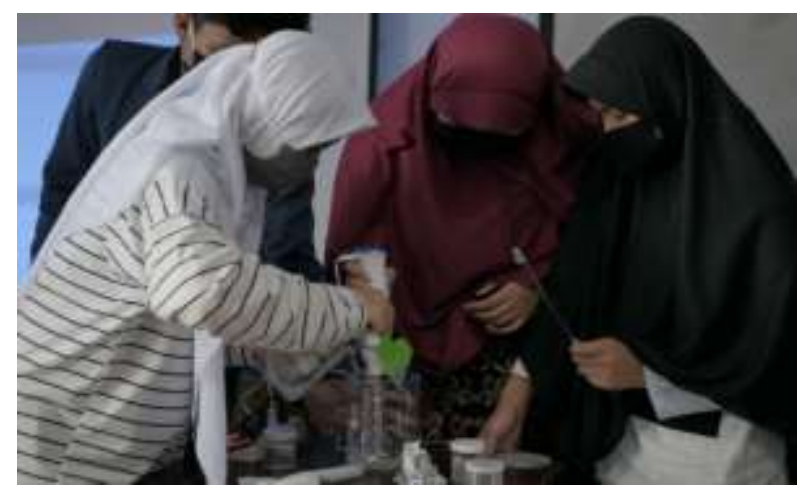

Gambar 3. Pelatihan pembuatan masker lidah buaya

Evaluasi yang dilakukan terkait pengabdian masyarakat menunjukkan bahwa 95\% dari peserta merasa pelatihan ini bermanfaat, sebanyak $70 \%$ dari peserta menyatakan proses pembuatan sediaan mudah. Sebanyak $70 \%$ akan membuat masker lidah buaya. Tanggapan positif terkait kegiatan pengabdian masyarakat dinyatakan dengan $100 \%$ peserta menyatakan penyajian materi menarik, materi yang disajikan mudah 
dipahami dan secara umum pesrta puas terhadap kegiatan pengabdian masyarakat pembuatan masker lidah buaya ini.

Kegiatan pengabdian ini disambut antusias oleh pihak sekolah karena dianggap dapat memberikan manfaat positif terhadap siswa di SMAIT Anak Sholeh Mataram. Pengabdian ini dikatakan sebagai media edukasi serta pengembangan skill siswa SMAIT Anak Sholeh Mataram, serta dapat mendukung visi sekolah tersebut serta memberikan pengetahuan pemanfaatan lain dari lidah buaya selain sebagai bahan makanan.

\section{Kesimpulan}

Telah dilaksanakan kegiatan Pelatihan pembuatan masker lidah buaya (Aloe vera) untuk mengatasi efek sunburn di SMAIT Anak Sholeh Mataram. Kegiatan berjalan lancar sesuai dengan rencana. Tanggapan positif yang diberikan oleh peserta ditandai dengan hasil 95\% dari peserta merasa pelatihan ini bermanfaat, sebanyak $70 \%$ dari peserta menyatakan proses pembuatan sediaan mudah. Sebanyak $70 \%$ akan membuat masker lidah buaya. Tanggapan terkait kegiatan pengabdian masyarakat dinyatakan dengan $100 \%$ peserta menyatakan penyajian materi menarik, materi yang disajikan mudah dipahami dan secara umum peserta puas terhadap kegiatan pengabdian masyarakat pembuatan masker lidah buaya ini.

\section{Saran}

\begin{abstract}
Saran untuk kegiatan pengabdian selanjutnya adalah dilakukan kegiatan pengembangan seperti kegiatan perancangan wadah dan pemasaran produk.
\end{abstract}

\section{Ucapan Terima Kasih}

Ucapan terimakasih penulis sampaikan kepada Universitas Mataram yang telah memberikan dukungan financial terhadap kegiatan ini. Selain itu, kepada tenaga pendidik
SMAIT Anak Sholeh yang telah membantu mensukseskan acara ini.

\section{Daftar Pustaka}

Badan Pusat Statistik Kota Mataram. (2019). Statistik Ketenagakerjaan Kota Mataram. Mataram: CC. Maharani.

Bhuvana, K. B., Hema, N. G., \& Patil, R. T. (2014). Review on aloe vera. International Journal of Advanced Research, 2(3), 677-691.

Geraldine, F. H., Anthony, I., Andrew, R., McGee., R. (2017). Unintended Sunburn: A Potential Target for Sun Protection Messages. Journal of Skin Cancer.

Hendradi, E., Chasanah, U., Indriani, T., Fionnayuristy, F. (2013) Pengaruh Gliserin Dan Propilenglikol Terhadap Karakteristik Fisik, Kimia dan SPF Sediaan Krim Tipe O/W Ekstrak Biji Kakao (Theobroma cacao L.) (Kadar Ekstrak Kakao 10\%, 15\% dan 20\%). PharmaScientia. 02(01)

Hekmatpou, D. (2019). The Effect of Aloe Vera Clinical Trials on Prevention and Healing of Skin Wound: A Systematic Review. Iran J Med Science, 44(1).

Jama Patient. (2015). Suntan and Sunburn. https://doi.org/10.1001/jama.2015.8045.S ources

Menteri Pendidikan dan Kebudayaan Republik Indonesia. Peraturan Menteri Pendidikan Dan Kebudayaan Republik Indonesia Nomor 6 Tahun 2019 Tentang Pedoman Organisasi Dan Tata Kerja Satuan Pendidikan Dasar Dan Menengaha (2019). Indonesia.

Rigano, L. (2014). Formulating Facial Masks. Cosmetics and Toiltries.

Rowe, R.C., Sheskey, P.J., Quinn, M. (2009). Handbook of Pharmaceutical Excipients. Fifth Edition. Pharmaceutical Press and American Pharmacist Association : Washington DC.

Sari, R., Nurbaeti, S.N., Pratiwi, L. (2016). Optimasi Kombinasi Karbopol 940 dan 
HPMC Terhadap Sifat Fisik Gel Ekstrak dan Fraksi Metanol Daun Kesum (Polygonum minus Huds.) dengan metode Simplex Lattice Design. Pharmaceutical Sciences \& Research. 3(2).

Septiadi, D., Nanlohy, P., Souissa, M., \& Rumlawang, F. Y. (2009). Proyeksi PotensiEnergi Surya Sebagai Energi Terbarukan (Studi Wilayah Ambon dan Sekitarnya). Jurnal Meteorologi Dan Geofisika, 10(1), 22-28.

Subaidah, W.A., Hajrin, W., Juliantoni, H. (2020). Formulasi dan Evaluasi Sifat Fisik Lotion Ekstrak Etanol Daun Kemuning (Murraya paiculata (L) Jack) dan Daun Lidah Buaya (Aloe vera Linn). Sasambo Journal of Pharmacy, 1(1), 12-16.

Suh, K., Roh, H., Choi, S., Jeon, Y., Doh, K., Bae, J., \& Kim, S. (2007). Long-term evaluation of erythema and pigmentation induced by ultraviolet radiations of different wavelengths. Skin Res Technology, 13(2).

Sunnah, I., Mulasih, S.W., Erwiyani, A.R. (2018). Optimasi Formula Dan Stabilitas Senyawa Metabolit Ekstrak Biji Labu Kuning (Cucurbita maxima) Dalam Sediaan Gel Masker Peel -Off. Indonesian Journal of Pharmacy and Natural Product. 01 (02).

Wilson, B. D., Moon, S., \& Armstrong, F. (2012). Comprehensive Review of Ultraof Ultraviolet Radiation and the, 5(9), 18-23. 